AGRICULTURE AND BIOLOGY JOURNAL OF NORTH AMERICA

ISSN Print: 2151-7517, ISSN Online: 2151-7525, doi:10.5251/abjna.2011.2.5.840.847

(C) 2011, ScienceHuß, http://www.scihub.org/ABJNA

\title{
Identification of agronomically valuable species of Crotalaria based on phenetics.
}

\author{
L. Joelri Michael Raj $^{1}$, S. John Britto ${ }^{1 *}$, S.Prabhu' ${ }^{1}$, \& S.R.Senthilkumar ${ }^{2}$. \\ ${ }^{1}$ The Rapinat Herbarium and Center for Molecular Systematics, St. Joseph's College, \\ Tiruchirappalli - 620 002, South India. \\ ${ }^{2}$ Department of Plant Biology and Plant Biotechnology, St. Joseph's College, \\ Tiruchirappalli - 620 002, South India.
}

\begin{abstract}
Numerical analyses of 58 morphological characters of 12 accessions belonging to Crotalaria were carried out by calculating similarity coefficients followed by cluster analysis, construction of dendrograms and PCO for visual appreciation of taxonomic relationship within this genus. The Jaccard's similarity coefficient varied between 0.738 and 0.998 and Nei's and Lei's similarity coefficient ranged between 0.870 and 0.998 , indicating closer relationships between the species selected. Among the 12 accessions C. verrucosa RHT56078 was suggested as a better alternative green manure due to its less susceptibility to pests and closer relationship with C.juncea. The present phenetic study had also picked out phylogenetically important characters for species identification within the genus and had also posed a resolved phylogenetic tree of evolutionary significance.
\end{abstract}

KEYWORDS: Genus Crotalaria, Numerical taxonomy, Morphology, UPGMA cluster, PCO.

\section{INTRODUCTION}

The genus Crotalaria $\mathrm{L}$. is the third largest genus of Papilionoideae, with about 600 species distributed throughout the tropics and subtropics (Polhill, 1982). Crotalaria is often easily recognized by its yellow flowers (but whitish to purplish or bluish flowers also occur) and its inflated pods. Crotalaria comprises herbaceous and shrubby species with simple, unifoliolate or digitately (3-7) foliolate leaves, stamens monadelphous with the sheath split at least at the very base, dimorphic anthers and inflated legumes. In general Crotalaria is adapted for a tropical climate and only a restricted number of species occurs in temperate regions. Crotalaria has a wide tolerance of edaphic conditions. The majority of species have a high light requirement, therefore they are absent from forest's interior, but are relatively common in clearings and forest margins (Polhill 1968, 1982).Crotalaria commonly known as rattlepods belong to the Nitrogen fixing clade. Their ability to fix nitrogen turns the attention of taxonomists to pick out the elite species among them. (Samba et al., 2002). Numerical approaches have been very less utilized for taxonomic purposes in Crotalaria, even though there seems to be ample scope for their applicability for an assessment of the taxonomic relatedness of the genus. Therefore a phenetic study was undertaken to trace the phylogenetic relationship among some economically important species of Crotalaria.

\section{MATERIALS AND METHODS:}

Collection of samples: The present investigation aims at the determination of the taxonomic relationship by using numerical analyses of 12 taxa at interspecific and intraspecific levels. RHT (Rapinat Herbarium, Tiruchirappalli) 56077 and RHT56060 were collected from the Western Ghats of Tamilnadu at high altitudes. Similarly RHT56081 and RHT56083 were collected from foothills of kollihills and puliyancholai hills respectively. The other accessions were from plains of central Tamil Nadu south India (Table - 1). Among the twelve accessions two accessions of C.verrucosa, C.retusa and C.grahamiana from widely separated geographical regions were chosen for study to measure the range of divergence that had occurred in the morphological traits within the species. Six herbarium specimens from each population of the accession were pressed and analyzed. The voucher specimens were identified at the Rapinat Herbarium and Center for Molecular Systematics, St. Joseph's College Tiruchirappalli, Tamil Nadu, India. The specimens were so processed as not to affect the leaves in terms of length and width and floral characters. 
However, it could change the colour and hence features as seen in the field were noted. Since all the herbarium specimens were pressed, the measurements are directly comparable with each other. Mature seeds were only were collected and stored at room temperature.

Table .1. List of species within the Genus Crotalaria taken for study:

\begin{tabular}{|r|l|l|l|l|l|}
\hline S.No & Accession No. & Botanical Name & Latitude & Longitude & Location and altitude \\
\hline 1 & RHT56077 & C.grahamiana & $10.27083^{\circ} \mathrm{N}$ & $77.56944^{\circ} \mathrm{E}$ & $\begin{array}{l}\text { Kodaikanal Ghat road, } \\
1835 \mathrm{~m} .\end{array}$ \\
\hline 2 & RHT56060 & C. beddomeana & $10.2372^{\circ} \mathrm{N}$ & $77.4714^{\circ} \mathrm{E}$ & $\begin{array}{l}\text { Kodaikanal S.H college, } \\
1327 \mathrm{~m} .\end{array}$ \\
\hline 3 & RHT56075 & C. retusa & $10.85444^{\circ} \mathrm{N}$ & $78.66417^{\circ} \mathrm{E}$ & Kambarasampettai, $68 \mathrm{~m}$. \\
\hline 4 & RHT56078 & C. verrucosa & $10.835^{\circ} \mathrm{N}$ & $78.73222^{\circ} \mathrm{E}$ & Keelmulaikudi, 71m. \\
\hline 5 & RHT56079 & C. juncea & $10.85545^{\circ} \mathrm{N}$ & $78.66518^{\circ} \mathrm{E}$ & Kambarasampettai, $72 \mathrm{~m}$. \\
\hline 6 & RHT56080 & C. paniculatus & $10.85570^{\circ} \mathrm{N}$ & $78.66558^{\circ} \mathrm{E}$ & Kambarasampettai, $73 \mathrm{~m}$. \\
\hline 7 & RHT56081 & $\begin{array}{l}\text { C. pallida var } \\
\text { pallida }\end{array}$ & $10.75354^{\circ} \mathrm{N}$ & $78.43291^{\circ} \mathrm{E}$ & Kolli hills, 754m. \\
\hline 8 & RHT56082 & $\begin{array}{l}\text { C. laburnifolia } \\
\text { subsp. laburnifolia }\end{array}$ & $10.85345^{\circ} \mathrm{N}$ & $78.66398^{\circ} \mathrm{E}$ & Kambarasampettai, $73 \mathrm{~m}$. \\
\hline 9 & RHT56083 & $\begin{array}{l}\text { C. pallida var } \\
\text { pallida }\end{array}$ & $10.73543^{\circ} \mathrm{N}$ & $78.77219^{\circ} \mathrm{E}$ & Puliancholai hills, 350m. \\
\hline 10 & RHT56084 & C. retusa & $10.83543^{\circ} \mathrm{N}$ & $78.73291^{\circ} \mathrm{E}$ & Cauvery river banks 65m. \\
\hline 11 & RHT56076 & C. verrucosa & $10.85450^{\circ} \mathrm{N}$ & $78.66554^{\circ} \mathrm{E}$ & Kambarasampettai, 73m. \\
\hline 12 & RHT56085 & $\begin{array}{l}\text { C.grahamiana } \\
10.85491^{\circ} \mathrm{N}\end{array}$ & $78.66468^{\circ} \mathrm{E}$ & Kambarasampettai, $73 \mathrm{~m}$. \\
\hline
\end{tabular}

Coding of the results: Multistate coding was used for the present study (Ramey et al., 1988). For the analysis 12 OTUs were scored for 58 characters, 36 qualitative characters out of which 26 qualitative characters are outlined in Table -2 and remaining 10 qualitative characters were special features that were coded for their presence/ absence. The features are : Curved Style, Style geniculate, Stipitate Ovary, Densely pubescent ovary, Stalked Ovary, Petiole, Horned Pods, Stipitate Pods, Bracteoles appressed to calyx, and Corolla twice as long as calyx. 22 quantitative characters are represented in Table - 3. 
Table - 2. List of Qualitative characters and character states used in numerical taxonomic analysis. (Phylogenetically important characters are indicated in bold letters).

\begin{tabular}{|c|c|c|c|c|c|c|c|}
\hline \multicolumn{8}{|c|}{ Qualitative characters } \\
\hline S.No & Characters & 1 & 2 & 3 & 4 & 5 & 6 \\
\hline 1. & Life Span & Annual & Perennial & & & & \\
\hline 2. & Habit & Herb & Subshrub & Shrub & & & \\
\hline 3. & Height of the plant & $1-2 m$ & $2-3 m$ & $3-4 m$ & & & \\
\hline 4. & Brachlets & Glabrous & Pubescent & $\begin{array}{l}\text { Densely } \\
\text { pubescent }\end{array}$ & Glandular & $\begin{array}{l}\text { Silky } \\
\text { pubescent }\end{array}$ & \\
\hline 5. & $\begin{array}{l}\text { Indumentum of the } \\
\text { leaves I leaflets }\end{array}$ & Glabrous & Pubescent & $\begin{array}{l}\text { Silky } \\
\text { tomentose }\end{array}$ & Villous & & \\
\hline 6. & Leaves & Simple & 3- Foliate & 5-7 - Foliate & & & \\
\hline 7. & Leaf / leaflet shape & Ovate & Obovate & Oblanceolate & Rhomboid & Oblong & Elliptic \\
\hline 8. & Leaf /leaflet Apex & Obtuse & Retuse & Acute & Rounded & & \\
\hline 9. & Leaf / leaflet Base & Cuneate & Attenuate & Obtuse & Acute & & \\
\hline 10. & Leaf / leaflet Margin & Entire & Ciliate & & & & \\
\hline 11. & Stipule & Semilunate & Pairs & Oblong falcate & Obscure & Subulate & Linear \\
\hline 12. & Infloroscence & Terminal Raceme & Lateral Raceme & Panicle & & & \\
\hline 13. & Bracts & Lanceolate & Linear & Subulate & Ovate & & \\
\hline 14. & Calyx tube & Glaborous & Pubscent & & & & \\
\hline 15. & $\begin{array}{l}\text { Corolla - Standard } \\
\text { petal }\end{array}$ & Ovate & Orbicular & Obovate & $\begin{array}{l}\text { Oblong } \\
\text { elliptic }\end{array}$ & & \\
\hline 16. & Corolla - wing petal & Obovate & Oblong & Elliptic & & & \\
\hline 17. & Corolla - Keels & Beak untwisted & Beak spirally twisted & & & & \\
\hline 18. & Corolla colour & Blue & Yellow & violet & & & \\
\hline 19. & $\begin{array}{l}\text { Corolla special } \\
\text { feature }\end{array}$ & $\begin{array}{l}\text { Reddish brown } \\
\text { colour }\end{array}$ & $\begin{array}{l}\text { reddish stripes } \\
\text { below }\end{array}$ & & & & \\
\hline 20. & Ovary & Glaborous & Pubscent & & & & \\
\hline 21. & Style & $\begin{array}{l}\text { Pubscent on the } \\
\text { inner side }\end{array}$ & $\begin{array}{l}\text { Pubscent on the } \\
\text { both sides }\end{array}$ & & & & \\
\hline 22. & Pods shape & Ellipsoid & Oblong & Oblong terete & $\begin{array}{l}\text { Oblong } \\
\text { clavate }\end{array}$ & & \\
\hline 23. & Pods indumentum & Glaborous & Pubscent & $\begin{array}{l}\text { Sparsely } \\
\text { pubscent }\end{array}$ & & & \\
\hline 24. & Pods size & $\begin{array}{l}\text { Slightly exceeding } \\
\text { Calyx }\end{array}$ & $\begin{array}{l}\text { Far exceeding } \\
\text { calyx }\end{array}$ & & & & \\
\hline 25. & Seed number & single seeded & Many seeded & & & & \\
\hline 26. & Seed shape & Reniform & Ovoid & & & & \\
\hline
\end{tabular}


Table - 3. List of quantitative characters and character states used in numerical taxonomic analysis. (Phylogenetically important characters are indicated in bold letters).

\begin{tabular}{|c|c|c|c|c|c|}
\hline \multicolumn{6}{|c|}{ Quantitative characters } \\
\hline S.No & Characters & 1 & 2 & 3 & 4 \\
\hline 1. & Leaf Size Length & $1.5-2.5 \mathrm{~cm}$ & $3-6 \mathrm{~cm}$ & $7-10 \mathrm{~cm}$ & $10-14 \mathrm{~cm}$ \\
\hline 2. & Leaf Size breadth & $0.5-1.0 \mathrm{~cm}$ & $1.0-2.0 \mathrm{~cm}$ & $2.0-4.0 \mathrm{~cm}$ & $4.0-7.0 \mathrm{~cm}$ \\
\hline 3. & Leaflet length & $3.0-5.0 \mathrm{~cm}$ & $6.0-10 \mathrm{~cm}$ & & \\
\hline 4. & Stipule Length & $1-2 \mathrm{~mm}$ & $1-2 \mathrm{~cm}$ & & \\
\hline 5. & Stipule width & $1-2 \mathrm{~mm}$ & $1-2 \mathrm{~cm}$ & & \\
\hline 6. & Petiole length & $1-5 \mathrm{~mm}$ & $6-10 \mathrm{~mm}$ & $1-5 \mathrm{~cm}$ & $6-10 \mathrm{~cm}$ \\
\hline 7. & Petiolule & $1.1-2.0 \mathrm{~mm}$ & $2.1-4.0 \mathrm{~mm}$ & & \\
\hline 8. & Leaflet breadth & $2.0-3.0 \mathrm{~cm}$ & $4.0-6.0 \mathrm{~cm}$ & & \\
\hline 9. & Panicle length & $1-10 \mathrm{~cm}$ & $10-20 \mathrm{~cm}$ & & \\
\hline 10. & Raceme length & $1-20 \mathrm{~cm}$ & $21-30 \mathrm{~cm}$ & $31-40 \mathrm{~cm}$ & \\
\hline 11. & Peduncle length & $1-3 \mathrm{~cm}$ & $3-6 \mathrm{~cm}$ & & \\
\hline 12. & Bract length & $1-5 \mathrm{~mm}$ & $6-10 \mathrm{~mm}$ & & \\
\hline 13. & Bracteoles & $1-3 \mathrm{~mm}$ & $4-6 \mathrm{~mm}$ & & \\
\hline 14. & Pedicel length & $1-5 \mathrm{~mm}$ & $6-10 \mathrm{~m} \mathrm{~m}$ & $1-2 \mathrm{~cm}$ & $3-4 \mathrm{~cm}$ \\
\hline 15. & Flowers across & $2-3 \mathrm{~cm}$ & $4-5 \mathrm{~cm}$ & & \\
\hline 16. & Flowers long & $2-3 \mathrm{~cm}$ & $4-5 \mathrm{~cm}$ & & \\
\hline 17. & Calyx tube & $1-2 \mathrm{~mm}$ & $3-5 \mathrm{~mm}$ & $1-2 \mathrm{~cm}$ & \\
\hline 18. & Length of the Pods & $1-2 \mathrm{~cm}$ & $4-5 \mathrm{~cm}$ & $6-7 \mathrm{~cm}$ & \\
\hline 19. & Breadth of the Pods & $0.1-1.0 \mathrm{~cm}$ & $1.1-2.0 \mathrm{~cm}$ & & \\
\hline 20. & Number of seeds & $1-5$ & $6-10$ & $15-20$ & $25-50$ \\
\hline 21. & Seeds Size & $1-2 m m$ & $3-4 \mathrm{~mm}$ & $5-6 \mathrm{~mm}$ & \\
\hline 22. & Staminal Sheath & $1-5 \mathrm{~mm}$ & $6-10 \mathrm{~mm}$ & & \\
\hline
\end{tabular}




\section{Data analysis:}

In numerical studies, the choice of method at each step is critically important (Duncan \& Baum, 1981). Two types of numerical methods namely Cluster analysis and PCO (Principle Coordinates Analysis) (James and McCulloch, 1990) were used. The results of cluster analysis were compared with those of PCO which gives a spatial relationship of individuals under study (Duncan and Baum, 1981; Radford, 1986; Hintum, 1995). Preference was for PCO rather than PCA (Principal Components Analysis), because a PCO performs better on data sets with missing data (Rohlf 1972). Assessment of similarities between accessions was carried out in two different ways; one by similarity coefficient and another by distance coefficient. The data were analysed using MVSP 3.1 (Multi Variate Statstical Package) for calculating Jaccards similarity coefficient, Nei's and lei coefficient and UPGMA dendrogram based on the similarity values. Squared Euclidean distances were calculated and PCO analysis was done based on the Euclidean distances. The distance matrix was also subjected to analysis in DAMBE 5.1.2. (Data Analysis for Molecular Biology and Evolution) to trace the phylogenetic relationship.

\section{Results and discussion: Cluster analysis:}

The dendrogram from Cluster Analysis of both qualitative and quantitative data sets using jaccards similarity coefficient and UPGMA is presented in Figure - 1 . The dendrogram was clearly divided into two clusters. The unifoliate species were separated into a single cluster. The other cluster contains trifoliate and multifoliate members. Thus conclusive dendrogram of total data sets shows that the nature of leaves to be simple or compound is a major feature in developing taxonomic key based on morphological characters. However majority of species of this genus are unifoliate species. Thus there is need to find many other diagnostic characters that could discriminate these unifoliate ones. The phenetic study proves its utility and had picked up phylogenetically important characters (Table - 2, 3) which is much emphasized in APG classification systems. Among the members of the unifoliate cluster (fig -1) C. juncea is agronomically much exploited. The present numerical study had revealed interesting facts in suggesting better alternatives for C.juncea that could be further exploited in future.
Fig - 1. Dendrogram based on 58 morphological characters using Jaccard's coefficient, Method UPGMA

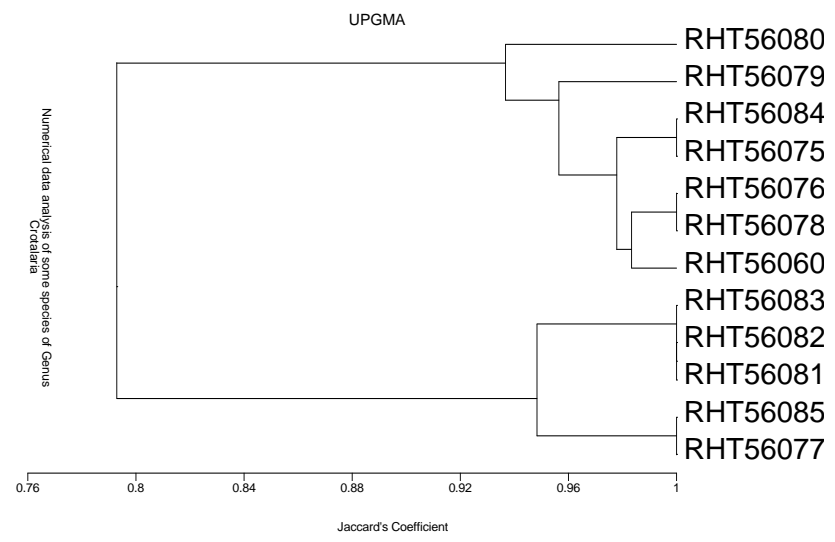

The conclusive dendrogram based on both qualitative and quantitative characters holds closer C.verrucosa and C.beddomeana together. Both the species are from widely separated geographical regions (Table 1). Characters from the leaf, stipules, seed and pod proved the most useful for the discrimination of these taxa from other species. However, most of the observed traits were not exclusive to a particular species and only the combined consideration of traits revealed coherent taxonomic groups. C. verrucosa seems to be the highly evolved entity among the unifoliate species. Many apomorphic characters like presence of semi-lunate stipules, rhomboid leaves discriminate this species from the rest. Although field observations reveal $C$. retusa to be highly susceptible to pests than C.verrucosa cluster analysis groups $C$. retusa with $C$.juncea as a much closer species with an average similarity value of $0.95, C$. verrucosa having a higher average similarity value of 0.96 is suggested as a better alternative green manure due to its less susceptibility to pests. Thus our phylogenetic study suggests C.verrucosa a better alternative to C.juncea. If the Nitrogen fixing ability is experimentally proved to be higher than $C$. juncea then the plant can be exploited as a multipurpose crop that can be used to improve the fertility of agricultural and waste lands. Moreover it is also highly exploited as an ethnomedicine by tribal populations (Nuhu et al., 2009). This investigation gives a scope to test the Nitrogen fixing ability of $C$. verrucosa.

C. verrucosa is also otherwise called the blue flower rattle pod having blue/ violet coloured flowers which 
is an exclusive feature in the genus Crotalaria. Among the two accessions of Crotalaria RHT56076 had violet coloured flowers and RHT56078 had blue coloured flowers. However RHT56078 was found to dominate the other variety growing as an erect subshrub having large sized leaves. But the similarity values clearly clusters them in to a single species (Fig - 1). A molecular analysis in different accessions of C.verrucosa could reveal interesting facts on genetic variation within the species. Though C.beddomeana (Synonym : C. lunata) was much closer to C. verrucosa, the habit of the plant seems to have high evolutionary significance since C.beddomeana (RHT56060), tends to grow as a prominent shrub with woody stem a feature common to the trifoliate ones like C.pallida and C. laburnifolia. The other species are herbs or subshrubs. However subshrubs are always preferred in agricultural fields as green manure. Thus habit of the plant should be emphasized which play an important role in selecting the agronomically useful variety. Similarly under reproductive characters corolla, pod and seed characters have high shannon's diversity index (data not shown) proving these characters as useful and significant characters. In the dendrogram C. pallida and $C$. laburnifolia together form a separate cluster (Fig - 1). Though C. pallida is always found to be in a different geographical region (hilly region) it shares high similarity with $C$. laburnifolia of 0.998 (Table - 4). Reddish brown stripes at the Keel petals and absence of stipules discriminate this cluster from other species studied. Thus the chemical profiles of C. pallida and C. laburnifolia should also be same.

Table - 4. Similarity matrix based on Jaccard's Coefficient.

\begin{tabular}{|c|c|c|c|c|c|c|c|c|c|c|c|c|}
\hline & 1 & 2 & 3 & 4 & 5 & 6 & 7 & 8 & 9 & 10 & 11 & 12 \\
\hline 1 & 1 & & & & & & & & & & & \\
\hline 2 & 0.844 & 1 & & & & & & & & & & \\
\hline 3 & 0.815 & 0.967 & 1 & & & & & & & & & \\
\hline 4 & 0.828 & 0.983 & 0.983 & 1 & & & & & & & & \\
\hline 5 & 0.797 & 0.95 & 0.95 & 0.966 & 1 & & & & & & & \\
\hline 6 & 0.785 & 0.934 & 0.934 & 0.95 & 0.917 & 1 & & & & & & \\
\hline 7 & 0.948 & 0.797 & 0.769 & 0.781 & 0.806 & 0.738 & 1 & & & & & \\
\hline 8 & 0.948 & 0.797 & 0.769 & 0.781 & 0.806 & 0.738 & 0.998 & 1 & & & & \\
\hline 9 & 0.948 & 0.797 & 0.769 & 0.781 & 0.806 & 0.738 & 0.998 & 0.998 & 1 & & & \\
\hline 10 & 0.815 & 0.967 & 0.998 & 0.983 & 0.95 & 0.934 & 0.769 & 0.769 & 0.769 & 1 & & \\
\hline 11 & 0.828 & 0.983 & 0.983 & 0.998 & 0.966 & 0.95 & 0.781 & 0.781 & 0.781 & 0.983 & 1 & \\
\hline 12 & 0.998 & 0.844 & 0.815 & 0.828 & 0.797 & 0.785 & 0.948 & 0.948 & 0.948 & 0.815 & 0.828 & 1 \\
\hline
\end{tabular}

Thus phenetics proves its robustness in identifying the closer species instead of relying on few vegetative characters which poses a great confusion in identifying species and deriving evolutionary relationships. An evolutionary tree obtained by importing the distance matrix to DAMBE 5.1.2. unveiled facets regarding the evolution of leaf structures which is well depicted in fig -3 . It traces the series of evolutionary changes that could have occurred within the genus in leaf structures. The trifoliate and pentafoliate leaves are expected to have evolved from the simple leaves of C.verrucosa. This could be explained by KNOX gene expression. The KNOX family has been implicated in leaf shape evolution from a simple leafed Arabidopsis thaliana to complex leaves of Cardamine hirsuta where in $A$. thaliana, the KNOX genes are completely turned off in leaves, but in C.hirsuta, the expression continued, generating complex leaves (Hay and Tsiantis, 2006). Also, it has been proposed that the mechanism of KNOX gene action is conserved across all vascular plants, because there is a tight correlation between KNOX expression and complex leaf morphology (Bharathan et al., 2002). A similar phenomenon is expected to have happened in evolution of leaf structures in Crotalaria which should be confirmed by molecular studies on KNOX gene expression in $C$. verrucosa and $C$. pallida. This shows that phenetics could also be used to derive a meaningful phylogeny. RAPD and Chloroplast DNA sequence variations can be more precise in identification of the species and to derive an authenticated phylogeny. 
Fig -3 Phylogenetic reconstruction with DAMBE 5.1.2 using Euclidean distance matrix.

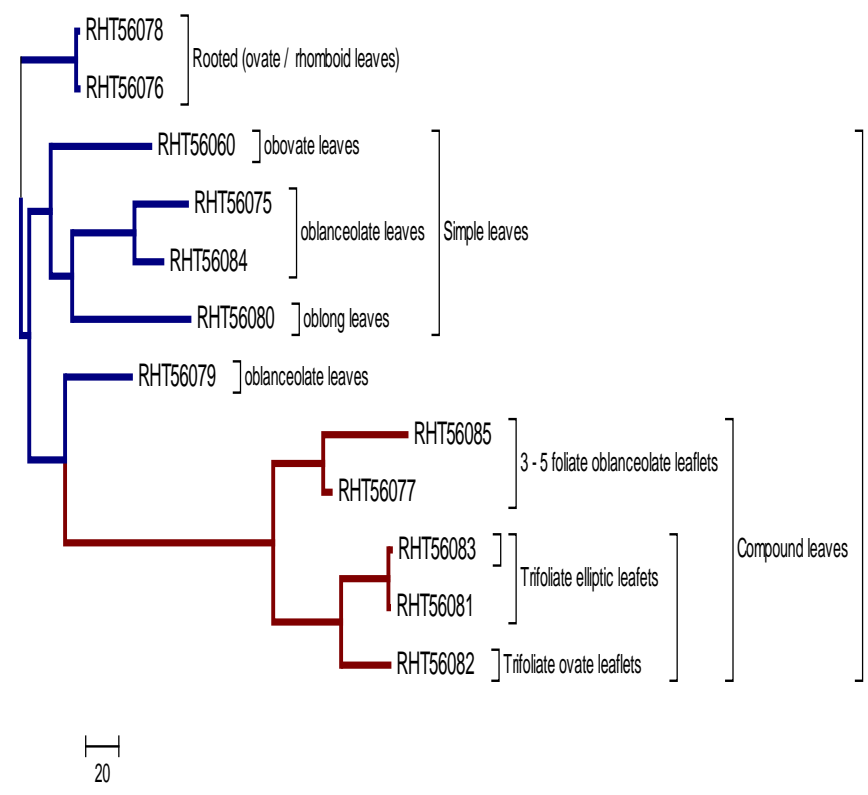

Fig - 3 - Tree caption: Phylogenetic tree from a user-supplied distance matrix, based on the FastME algorithm (Desper and Gascuel 2002, 2004), with branch evaluation by the balanced method and with the initial tree generated by the GME method. The final tree results from evaluating candidate trees generated by extensive $\mathrm{NNI}$ (nearest neighbor interchange). (Xia 2001; Xia and Xie 2001). The tree is rooted by outgroup RHT56076.

PCO (Principle Coordinate analysis): Cluster analysis can identify clusters of phenetically related accessions; it fails to delimit some in a precise manner. PCO places them somewhere in between groups to indicate what position they specifically occupy in relation to all other accessions. Principal coordinate analysis has the advantage of showing how accessions and clone sets are phenetically related by indicating how distant each accession is from all others. The distance between the two accessions of $C$. grahamiana is depicted well in PCO (fig - 2). Whereas the two accessions of $C$. verrucosa (RHT56076 and RHT56078) and C. retusa (RHT56075 and RHT56084) lie closer. This shows that huge morphological variations have occurred within the two accessions of C.grahamiana RHT56077 and RHT56085 which were collected from two different ecological habitats (Table - 1). Usually many species of C.grahamiana occurs only in forest margins of Western Ghats. They are characterized by the presence of silky pubscent hairs, a feature which

Fig -2. Principle Coordinate analysis (PCO) for 12 accessions based on 58 morphological characters.

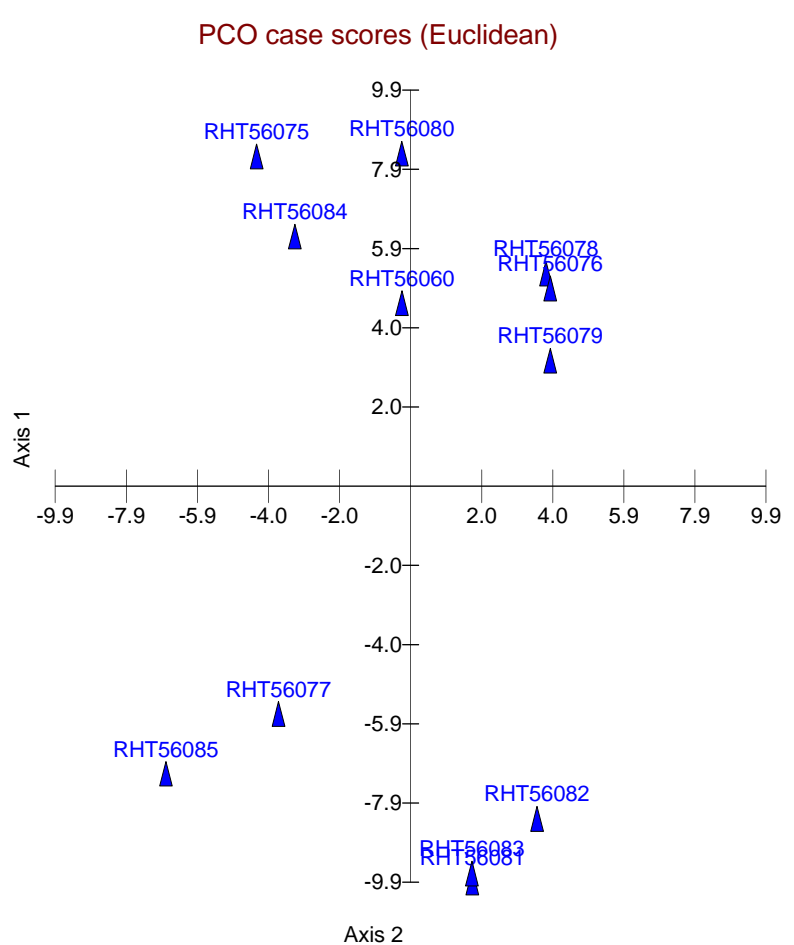

was absent in RHT56085. The occurrence of RHT56085 C.grahamiana in hay fields is a new finding. The special advantageous feature in this clone is occurrence of more than 30 seeds in the pod whereas the RHT56077 had hardly 15 seeds in a pod. Thus PCO analysis had segregated the two accessions where both the accessions can be separately tested for its nitrogen fixing capability to identify the elite clone. C. grahamiana is already exploited as a green manure in many African countries. However, acceptance of $C$. grahamiana was hampered by its susceptibility to pest attack, which farmers perceive as infesting their leafy crops (Tumuhairwe et al., 2007). Thus PCO points to the variables as the most responsible for giving that pattern of relationships among these accessions. However cluster analysis identifies clusters among individuals based on the given variable which was the first objective of this investigation. PCO can then support or not support the clusters generated by 
cluster analysis. Cluster analysis can further indicate how similar each accession is to each other, a procedure found to be very useful in distinguishing accessions likely to be phenetic duplicates or clones. Thus cluster analysis and PCO complement each other and it is therefore useful to apply them simultaneously.

\section{CONCLUSION:}

Since Numerical taxonomy uses a large number of characters and confers equal weightage to all characters the classification obtained by numerical taxonomy presents more information than did conventional methods on the relationship between the species of Crotalaria used in the present study. The results of this study have clearly pointed to the usefulness of numerical methods in resolving the obscured relationships between taxonomic units. Although this study added new findings to the literature, it is somewhat limited to the known species and subspecies distributed in the central Tamilnadu. A comprehensive study covering a few more economically important species of Crotalaria from the Western Ghats seems to be necessary to construct a more satisfactory classification and also it would be much better to use molecular data which could support the morphological characters used in this study.

\section{ACKNOWLEDGEMENT:}

The author Joelri Michael Raj. L is thankful to Dr. S. John Britto, The Director, The Rapinat Herbarium and centre for Molecular systematics for identification of Plant specimens.

\section{REFERENCES:}

Bharathan G., Thomas E.G., Christopher, M., Sharon, K., Thinh, P. and Neelima, R.S. (2002). "Homologies in Leaf Form Inferred from KNOXI Gene Expression during Development". Science 296(5574): 1858-1860.

Desper, R. and Gascuel. O. (2002). Fast and accurate phylogeny reconstruction algorithms based on the minimum-evolution principle. Journal of Computational Biology 9:687-705.

Desper, R. and. Gascuel, O. (2004). Theoretical foundation of the balanced minimum evolution method of phylogenetic inference and its relationship to weighted least-squares tree fitting. Mol Biol Evol 21:587-98.

Duncan, T. and Baum, B.R. (1981). Numerical phenetics: its uses in botanical systematics. Annual Review of Ecology and Systematics 12: 387-404.
Hay and Tsiantis, M. (2006). "The genetic basis for differences in leaf form between Arabidopsis thaliana and its wild relative Cardamine hirsuta". Nat. Gen. 38 (8): 942-947.

Hintum, T.J.L. (1995). Hierarchical approaches to the analysis of genetic diversity in crop plants. In: Hodgkin, T., Brown, A.H.D., Hintum, Th.J.L. van and Morales, E.A.V.(eds.) Core Collections of Plant Genetic Resources, pp. 77-92. John Wiley and Sons, Chichester.

James, F.C. and McCulloch, C.E. (1990). Multivariate analysis in ecology and systematics: panacea or pandora's box? Annu. Rev. Ecol. Syst. 21:129-166.

Nuhu, H., Abdurrahman, E. M., and Shok, M. (2009). Ethnomedical studies of Crotalaria species found in Zaria, Northern Nigeria. Nigerian journal of pharmaceutical sciences vol. 8 (2): $46-53$

Polhill, R. M. (1968). Miscellaneous notes on African species of Crotalaria. II. Kew Bulletin 22: 169-348.

Polhill, R. M. (1982). Crotalaria in Africa and Madagascar. Royal Botanic Gardens, Kew, pp389.

Radford, A.E. (1986). Fundamentals of plant systematics. Harper and Row, Publishers, Inc.

Ramey, T.B., Waines, J.G. and Mosjidis, A.J. (1988). Detection of repeated genotypes among 93 diploid wheat accessions. Euphytica 37: 283-287.

Rohlf, F. J. (1972). An empirical comparison of three ordination techniques in numerical taxonomy. Syst. Zool. 21: 271-280.

Samba, R.T., Sylla S.N., Neyra, M., Gueye, M., Dreyfus, B. and Ndoye, I. (2002). Biological nitrogen fixation in Crotalaria species estimated using the ${ }^{15} \mathrm{~N}$ isotope dilution method, African Journal of Biotechnology Vol. 1 (1): 17-22.

Tumuhairwe, J.B., Rwakaikara-Silver, M.C., Muwanga, S. and Natigo, S. (2007). Screening Legume Green Manure for Climatic Adaptability and Farmer Acceptance in the Semi-Arid Agro-ecological Zone of Uganda, Advances in integrated soil fertility management in sub-saharan africa: challenges and opportunities pp. 255-259,

Xia, X. (2001). Data analysis in molecular biology and evolution. Kluwer Academic Publishers, Boston.

Xia, X. and. Xie, Z. (2001). DAMBE: Software package for data analysis in molecular biology and evolution. $\mathrm{J}$. Hered. 92:371-373. 